\title{
The value of a small urban green area to the medium and large-sized mammals conservation
}

O valor de uma pequena área verde urbana para a conservação de mamíferos de médio e grande porte

El valor de una pequeña zona verde urbana para la conservación de mamíferos medianos y grandes

\begin{abstract}
Brazil presents the biggest mammal diversity in the world, 755 species, of which 110 are classified under some degree of threat. In the São Paulo State is an estimated 350 taxa richness, however, this number can be even higher due to the gap of sampling over large extensions. In addition, many urban green areas are not studied because their value is underestimated for biodiversity conservation. In this way, the present study aimed to survey the medium and largesized terrestrial mammals in a Municipal Conservation Unit located in the urban area of Franca, SP. Using cameras trap, sand plots, and active search, in the period between May and July 2019, 16 mammals were sampled. The highest number of species was identified through sand plots (12), followed by active search (7) and cameras trap (4). The sampled community is mostly composed of opportunistic and generalist species with few predators. Among species found, the maned wolf (Chrysocyon brachyurus) is classified nationally as vulnerable to extinction. Despite the significant number of sampled species, the species accumulation curve obtained did not reach its asymptote. Thus, it is concluded that Zoobotanic Garden, despite suffering strong anthropic pressure, develop an important role in the regional medium and large-sized terrestrial mammals conservation, acting as a refuge area for these species.
\end{abstract}

Keywords: Mammals; Northeastern paulista; Conservation unit.

\section{Resumo}

O Brasil apresenta a maior diversidade de mamíferos do mundo, 755 espécies, das quais 110 estão classificadas sob algum grau de ameaça. No Estado de São Paulo, estima-se a riqueza de 350 táxons, no entanto, esse número pode ser ainda maior devido à lacuna de amostragem em grandes extensões. Além disso, muitas áreas verdes urbanas não são estudadas porque seu valor é subestimado para a conservação da biodiversidade. Desta forma, o presente estudo teve como objetivo fazer um levantamento dos mamíferos terrestres de médio e grande porte em uma Unidade de Conservação Municipal localizada na zona urbana de Franca, SP. Usando armadilhas fotográficas, parcelas de areia e 
busca ativa, no período de maio a julho de 2019, foram amostrados 16 mamíferos. O maior número de espécies foi identificado por meio de parcelas de areia (12), seguido de busca ativa (7) e armadilha fotográfica (4). A comunidade amostrada é composta principalmente por espécies oportunistas e generalistas com poucos predadores. Dentre as espécies encontradas, o lobo-guará (Chrysocyon brachyurus) é classificado nacionalmente como vulnerável à extinção. Apesar do número significativo de espécies amostradas, a curva de acumulação de espécies obtida não atingiu sua assíntota. Assim, conclui-se que o Jardim Zoobotânico, apesar de sofrer forte pressão antrópica, desempenha papel importante na conservação dos mamíferos terrestres regionais de médio e grande porte, atuando como área de refúgio para essas espécies.

Palavras-chave: Mamíferos; Nordeste paulista; Unidade de conservação.

\section{Resumen}

Brasil tiene la mayor diversidad de mamíferos del mundo, 755 especies, de lãs cuales 110 están clasificadas bajo algún grado de amenaza. En el Estado de São Paulo, se estima que 350 taxones son ricos, sin embargo, ese número puede ser aún mayor debido a la brecha de muestreo en áreas extensas. Además, muchas áreas verdes urbanas no se estudian porque se subestima su valor para La conservación de la biodiversidad. Así, el presente estúdio tuvo como objetivo el relevamiento de mamíferos terrestres medianos y grandes en una Unidad de Conservación Municipal ubicada en el área urbana de Franca, SP. Utilizando cámaras trampa, parcelas de arena y búsqueda activa, de mayo a julio de 2019, se muestrearon 16 mamíferos. El mayor número de especies se identificó mediante parcelas de arena (12), seguido de búsqueda activa (7) y cámara trampa (4). La comunidad muestreada está compuesta principalmente por especies oportunistas y generalistas com pocos depredadores. Entre las especies encontradas, el lobo de crin (Chrysocyon brachyurus) está clasificado a nivel nacional como vulnerable a la extinción. A pesar del importante número de espécies muestreadas, la curva de acumulación de espécies obtenida no alcanzó su asíntota. Así, se concluye que el Jardín Zoobotánico, a pesar de sufrir una fuerte presión antrópica, juega un papel importante en la conservación de los mamíferos terrestres regionales medianos y grandes, actuando como área de refugio para estas especies.

Palabras clave: Mamíferos; Nordeste paulista; Unidad de conservación.

\section{Introduction}

The mammals develop fundamental role in the ecosystems balance, engaging in many ecological process (Terborgh \& Soulé, 1999), such as prey population control, through the top down effect (Begon et al., 1996), and the constant forests regeneration, through seeds dispersal of many vegetal species (Tonhasca Júnior, 2005). Some mammals species are considered enviromental indicators, indicating the conservation degree of the place where they occur, others are considered key species, for maintaining the ecossystem diversity of terrestrial communities (Mazzolli, 2006).

Nowadays, about 6.495 mammals species are recognized, a number that continues being updated as new species are discovered (Burgin et al., 2018). Between 2014 and 2015, only in the Amazon, were described over 20 species (Valsecchi et al., 2017). Brazil is considered the country with the highest concentration of mammals biodiversity on the planet (Mittermeir et al., 1997; Lewinsohn \& Prado, 2002). There are 755 recognized mammals species, distributed on 11 orders, 51 families and 249 genera, and the orders with the largest number of species are Rodentia (257), Chiroptera (182) e Primates (128) (Abreu Júnior et al., 2020). Of this community, there are 110 species classified in some category of extinction risk, which $61 \%$ are endemic of country (Instituto Chico Mendes de Conservação da Biodiversidade, 2018). Part of these endemisms are located in two biomes, Cerrado and Mata Atlântica, which are considered biodiversity hostpots, that is, areas with high richness and big rate of endemisms, priorities to conservation (Mittermeier et al., 2000). In the first, there are 41 mammals species considered threatened, which 12 are endemic, and in the second, 53 are threatened, which 31 are endemic (Instituto Chico Mendes de Conservação da Biodiversidade, 2018).

Few forest fragments remain from these biomes in the State of São Paulo. The Atlantic Forest presents only $32.6 \%$ of its original formation, while the Cerrado just 3\% (Nalon et al., 2020). These fragments have their functional role for biodiversity conservation compromised, due to human disturbances, which causes, in most cases, habitat loss and fragmentation, the major threats to continental mammals (Rodrigues \& Bononi, 2008). In the São Paulo State there are about 350 mammals species (SpeciesLink, 2019), however, this number may be even higher due to the lack of sampling in large 
extensions and the absence of taxonomic revisions for certain groups (De Vivo et al., 2011). There are 38 species classified in some degree of threat to extinction, 58\% of which are medium and large (Bressan et al., 2009).

The degree of threat and the ecological importance of the group make evident the need to add new information about terrestrial mammals, from inventories and environmental diagnoses, contributing to the elaboration of proposals for mammals conservation (Wolfart et al., 2013; Cooke et al., 2019). Thus, the aim of this study was to carry out a survey of the medium and large sized terrestrial mammals community, assess the richness and highlight the relevant information on the local situation of the species that occur in the Conservation Unit of Franca city, SP.

\section{Methodology}

The related research has a descriptive character, with a quali-quantitative approach, in which the numerical results are collected by qualitative (Köche, 2011; Culen et al., 2012; Pereira et al., 2018).

\section{Study area}

The study area is located in the Franca city, northeast of São Paulo State, being a municipal Conservation Unit, designated by Zoobotanic Garden $\left(20^{\circ} 28^{\prime} 37.7^{\prime \prime S ~} 47^{\circ} 24^{\prime} 10.9^{\prime \prime} \mathrm{W}\right)$ (Figure 1). The altitude is 1040 meters and the climatic classification, according to Köppen-Geiger, is subtropical altitude climate (Alvares et al., 2013). It has an average annual precipitation of $1,644 \mathrm{~mm}$ and average temperature between $13^{\circ} \mathrm{C}$ and $28^{\circ} \mathrm{C}$.

Figure 1.Geographic location of Zoobotanic Garden of Franca, SP.

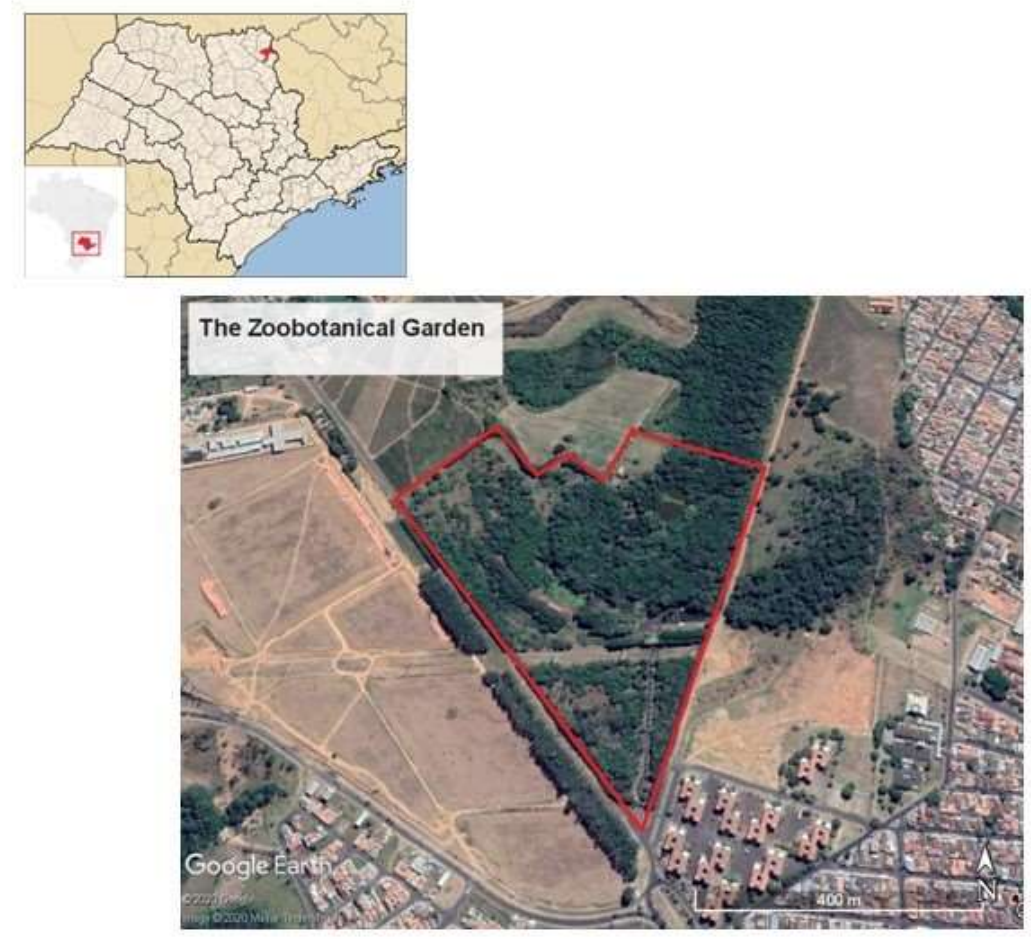

Source: Google Earth (2020).

The vegetation presents phytophysiognomies elements of the Cerrado and Atlantic Forest, being the first found mainly in the higher areas, with soils derived from the decomposition of sandstones, and the second restricted to slopes and low parts. Thus, the site is recognized as an ecotone, a transition area between these two biomes (Vieira, 1971; Marqueti, 1991; Rodrigues et al., 2008). 
The Conservation Unit of the study was created through Municipal Law No. 5,048 of July 17, 1998, aiming at the conservation of the plant and animal species. The area is in the Pouso Alto Municipal Public Farm, with 200 hectares, of which 26 hectares are used for the production and supply of seedlings, for reforestation and urban afforestation purposes. There are also public visits and monitored, with actions of environmental education, scientific research, leisure and ecological tourism.The area is home to small dams and also the Pouso Alto river spring, which supplies the Franca city, belonging to the Sapucaí-Mirim/Grande Hydrographic Basin (Franca, 2016).

\section{Data collection}

It was conducted from May 3 to July 12, 2019, by the methods, not simultaneous, sand plots, cameras trap and active search, detailed below.

\section{Sand plots}

This method was used to sample footprints of mammals species, had been the first realized by the present inventory. Four plots of sand were made, each $1 \mathrm{~m}^{2}$ and $2 \mathrm{~cm}$ high, filled with fine sand, adapted from the method described by Becker and Dalponte (2013). The sampling points were chosen according to prior knowledge of the passage of mammals through the area (Figure 2).

Figure 2. Geographic distribution of sand parcels in the Zoobotanic Garden of Franca, SP.

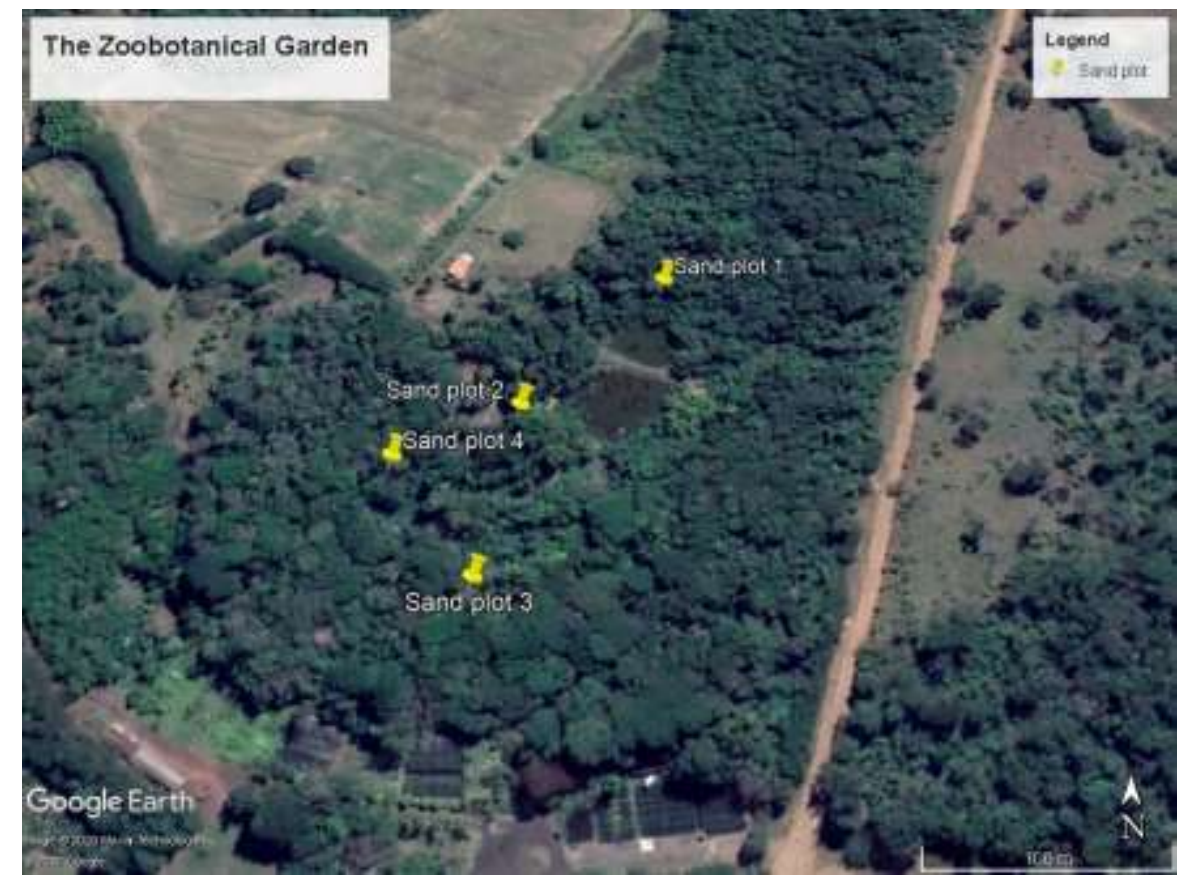

Source: Google Earth (2020).

In these sites baits were added, such as apples, bananas, papayas, peanut butter, bacon, cinnamon, sardines and salt. All plots were covered for five consecutive days per week, between the morning and afternoon periods, checking for the presence of footprints. The natural banks of clayey soil were also checked, on the trails and near water courses. The footprints were photographed for later identification, with the aid of objects for references of the size of the tracks. After sampling data, the sand plots underwent maintenance, removing the litter and, if necessary, replacing and humidifying the sand, and replacing 
the baits. Footprint identification was based on Becker and Dalponte (2013), Ramos Júnior and collaborators (2003), Carvalho Júnior e Luz (2008) and Moro-Rios and collaborators (2008).

\section{Cameras trap}

After the beggining of inventory by sand plots, started the sampling data by cameras trap, between days 28 may and 2 july, 2019, using camera trap HC $700 \mathrm{mg}$ 16MP. This method provides the identification of species that are often not possible to be sampled by footprints, in addition to being useful in the study of animals with nocturnal, stealthy habits or that occur in low densities (Karanth et al., 2003; Tomas \& Miranda, 2003). The camera trap was installed close to the sand plots, in areas furthest from trails, forest edges and water bodies, in seven strategic sampling points (Figure 3).

Figure 3. Geographic arrangement of the photographic trapping points in the Zoobotanic Garden of Franca, SP.

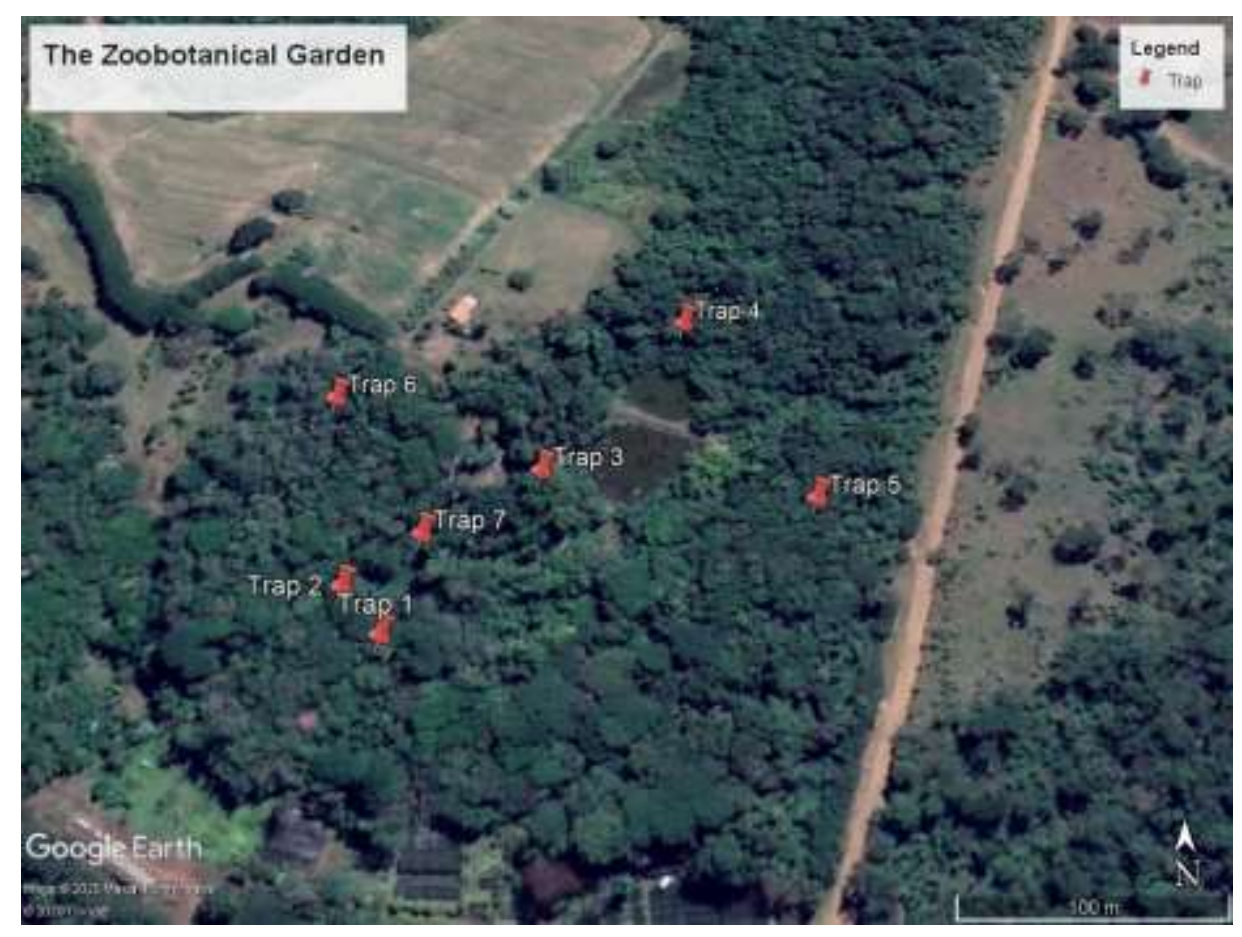

Source: Google Earth (2020).

This was active for five days and exchange of points made every 48 hours on a rotating system, being removed on weekends to prevent theft. The camera was fixed on tree trunks, with an approximate height of $30 \mathrm{~cm}$ above the ground, and each location was provided with baits (salt, cinnamon, bacon, banana, apple, papaya, guava, coarse salt, peanut butter and sardines), to attract terrestrial mammals present.

\section{Active search}

Data collection was also carried out through the active search method, in which the entire UC area was randomly searched for signs, such as tracks, feces, vocalizations and mammalian visualizations. They were carried out during the daily check of the sand plots, in addition to the entire area of trails and edges of the forest at the Zoobotanic Garden having been covered during data collection. The displacements were carried out in silence, examining from the ground to higher strata and with brief stops for observation. 


\section{Data analysis}

The sampling effort for the plots method was calculated considering the number of sand plots multiplied by the number of days sampled (Silva, 2001). In the camera trap method the sampling effort was calculated through the number of sampled points multiplied by the number of days the cameras operated (Srbek-Araújo \& Chiarello, 2007). For the active search, the sampling effort was calculated as the total kilometers covered multiplied by the number of days sampled. The sampling success of each method was expressed as a percentage (number of records/sampling effort x 100) (Srbek-Araújo \& Chiarello, 2007). For camera trap and active search, the views and photos obtained in an interval of 30 minutes were considered as a single record. For the sand plots, the records were counted per day, that is, considered a single record per day for each species. The total sampling effort was expressed graphically, through the species accumulation curve, with a $95 \%$ confidence interval, and the rarefaction curve was calculated in the Past 3.0 program (Hammer et al., 2001).

\section{Results and Discussion}

It was sampled 16 species of medium and large sized mammals (Table 1), distributed in seven orders and 12 families, have been more significant the order Carnivora (Figure 4). Among the methods used in the study, which showed higher efficiency was sand plot, with 12 recorded species (Figure 5). There were 52 days of collection and a sampling effort of 208 plots/day. Six species were only registered by this method: maned wolf (Chrysocyon brachyurus), yellow armadillo (Euphractus sexcinctus), nine-banded armadillo (Dasypus novemcinctus), Brazilian rabbit (Sylvilagus brasiliensis), cavy (Cavia aperea) and Red-rumped agouti (Dasyprocta leporina). This result highlights the importance of sand plots in surveys of terrestrial mammals, corroborating Santos and collaborators (2013), a study in which the greatest richness was obtained with the use of these, when compared to methods of camera traps and active search. In the same study, the species nine banded armadillo (D. novemcinctus) and tapiti (S. brasiliensis) were also registered only by sand plots.

The camera trap method, although it only sampled four species, contributed greatly to the nocturnal records and verification of the species' activity times, having been crab-eating Fox (Cerdocyon thous) exclusively registered by this method (Figure 6). The sampling effort was 182 traps/day, which is low and may explain the lower amount of species registration. The disadvantage observed in its use refers to the susceptibility to theft and depredation of the equipment, a fact that interfered in the choice of the sampling points, in more closed areas, and perhaps less passage of animals (Marques \& Mazim, 2005). Small rodents, bats, an amphibian, labyrinth Frog (Leptodactylus labyrinthicus) and three birds species, the bare-faced Curassow (Crax fasciolata), White-tipped Dove (Leptotila verreauxi) and the Rusty-margined Guan (Penelope superciliaris), the first being threatened with extinction (International Union for Conservation of Nature and Natural Resources, 2016). 
Table 1. List of species sampled at Zoobotanic Garden of Franca, SP. Foot $=$ Footprints, feces and vocalization, Trap $=$ camera trap, Vis = direct visualization.

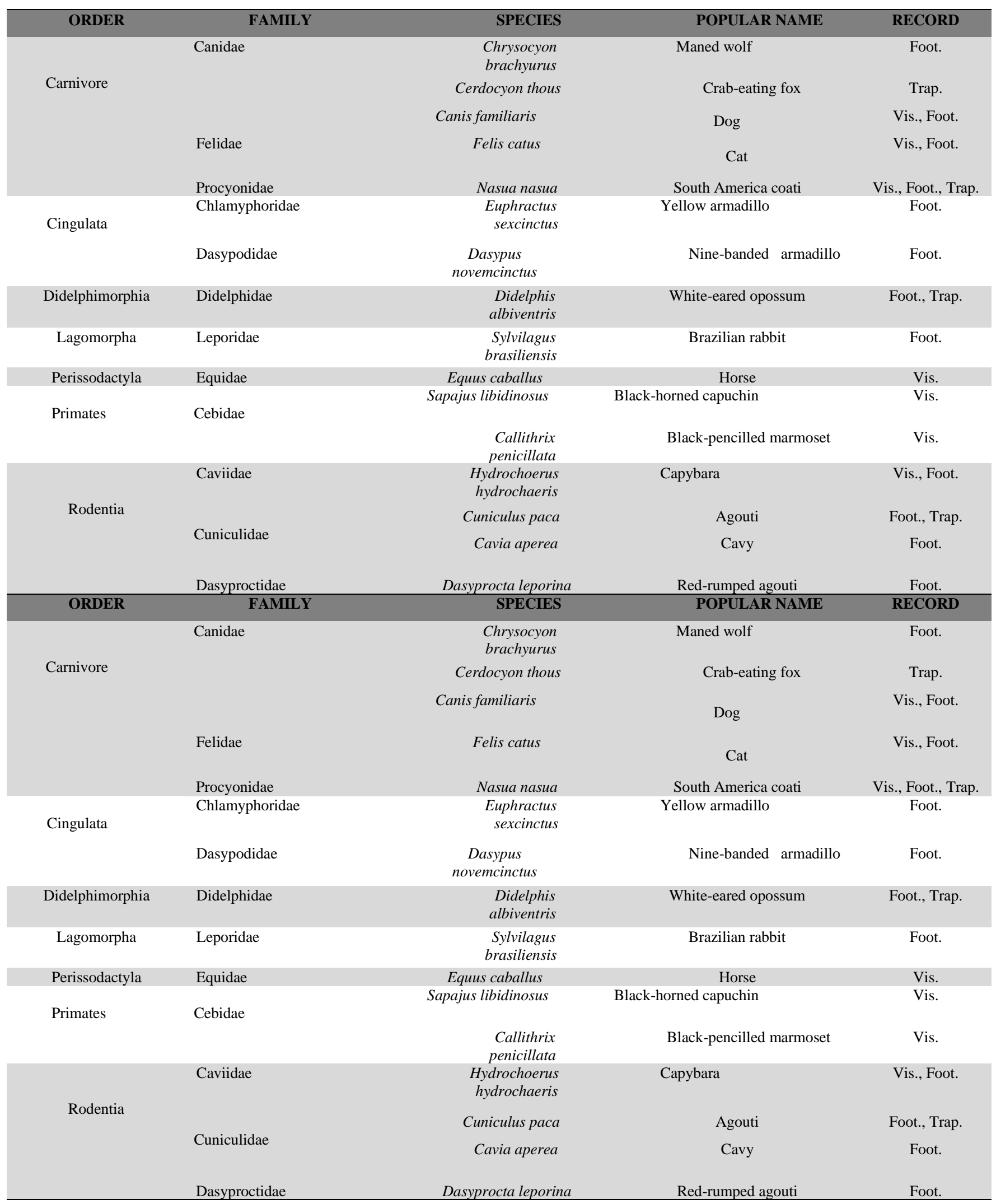

Source: Authors. 
Figure 4. Graph of the percentage of orders of land mammals sampled.

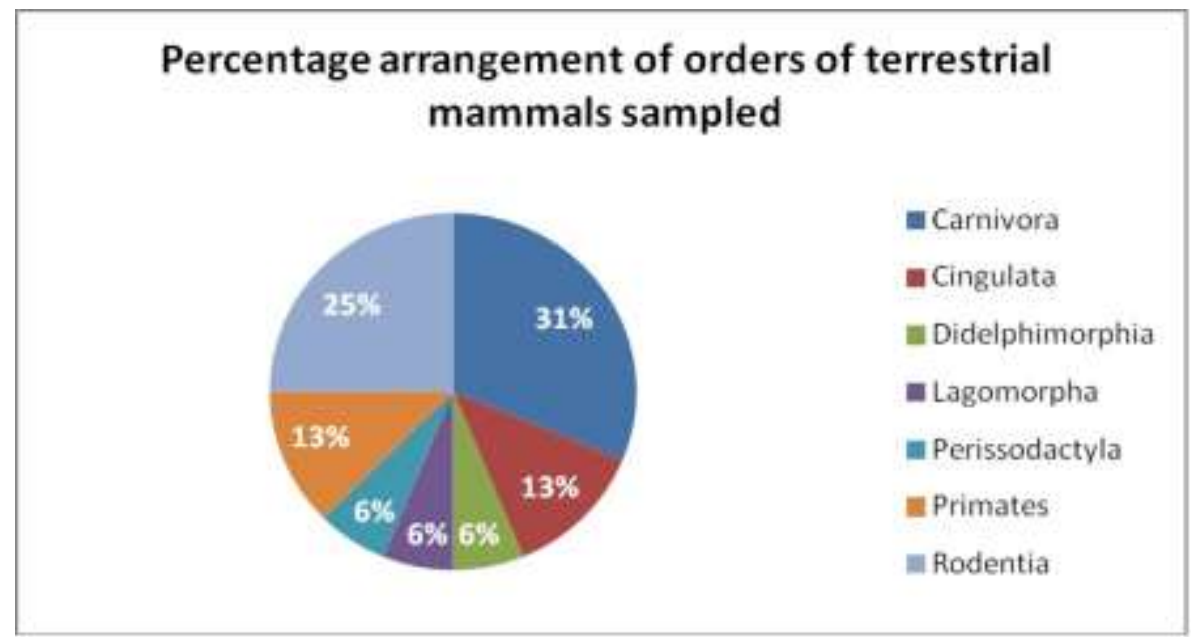

Source: Authors.

Figure 5. Records in the sand parcels at the Zoobotanic Garden of Franca, SP. A: Maned wolf (Chrysocyon brachyurus), B: South America coati (Nasua nasua), C: Cat (Felis catus), D: Dog (Canis familiaris), E: Brazilian rabbit (Sylvilagus brasiliensis), F: Yellow armadillo (Euphractus sexcinctus), G: White-eared opossum (Didelphis albiventris); H: Agouti (Cuniculus paca), I: Nine-banded armadillo (Dasypus novemcinctus) J: Capybara (Hydrochoerus hydrochaeris), K: Cavy (Cavia aperea), L: Red-rumped agouti (Dasyprocta leporina).
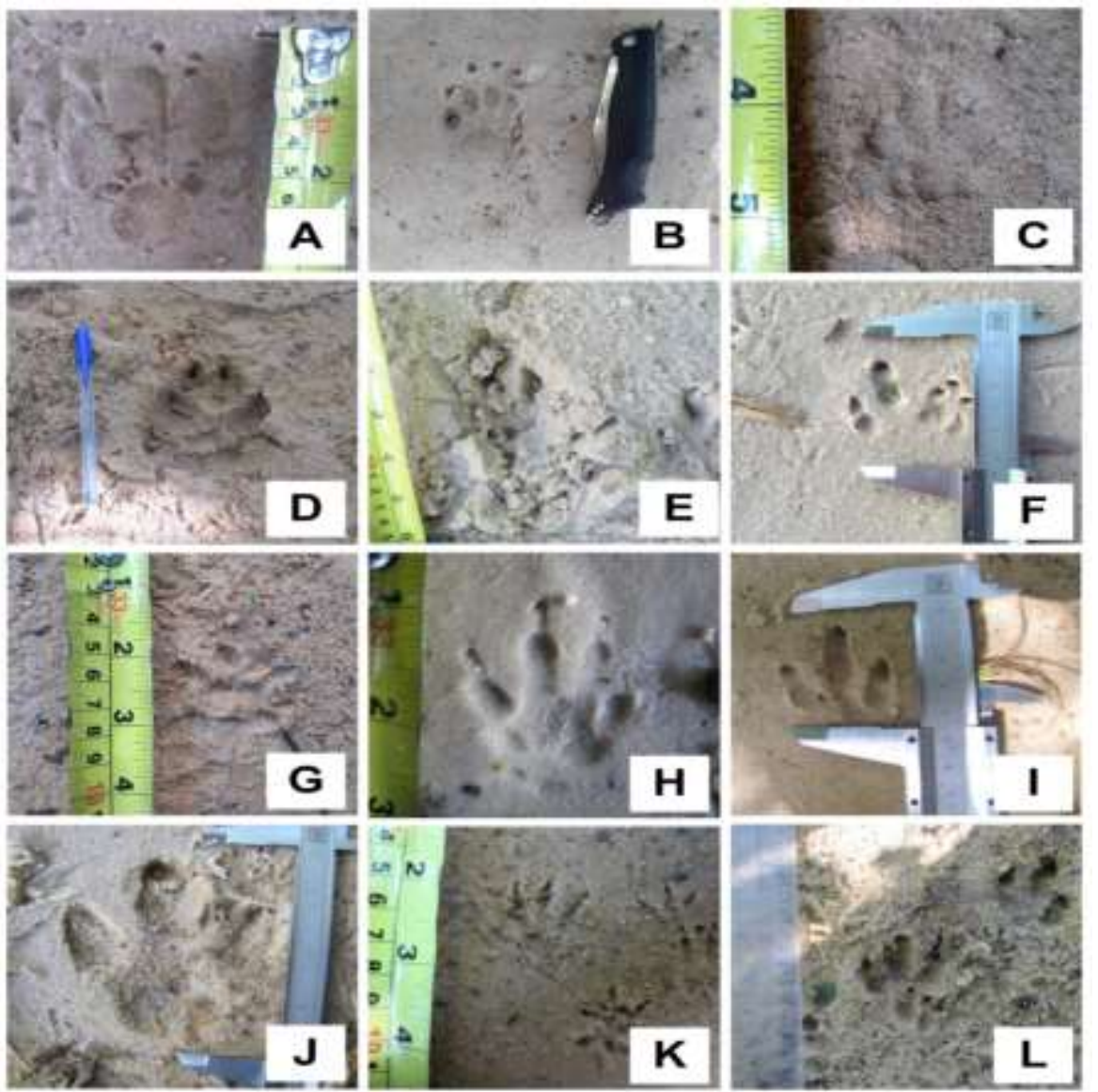

Source: Authors. 
Figure 6. Species records by the camera trap at the Zoobotanic Garden of Franca, SP. A: Crab-eating fox (Cerdocyon thous), B: South American coati (Nasua nasua), C: White-eared opossum (Didelphis albiventris) e D: Agouti (Cuniculus paca).

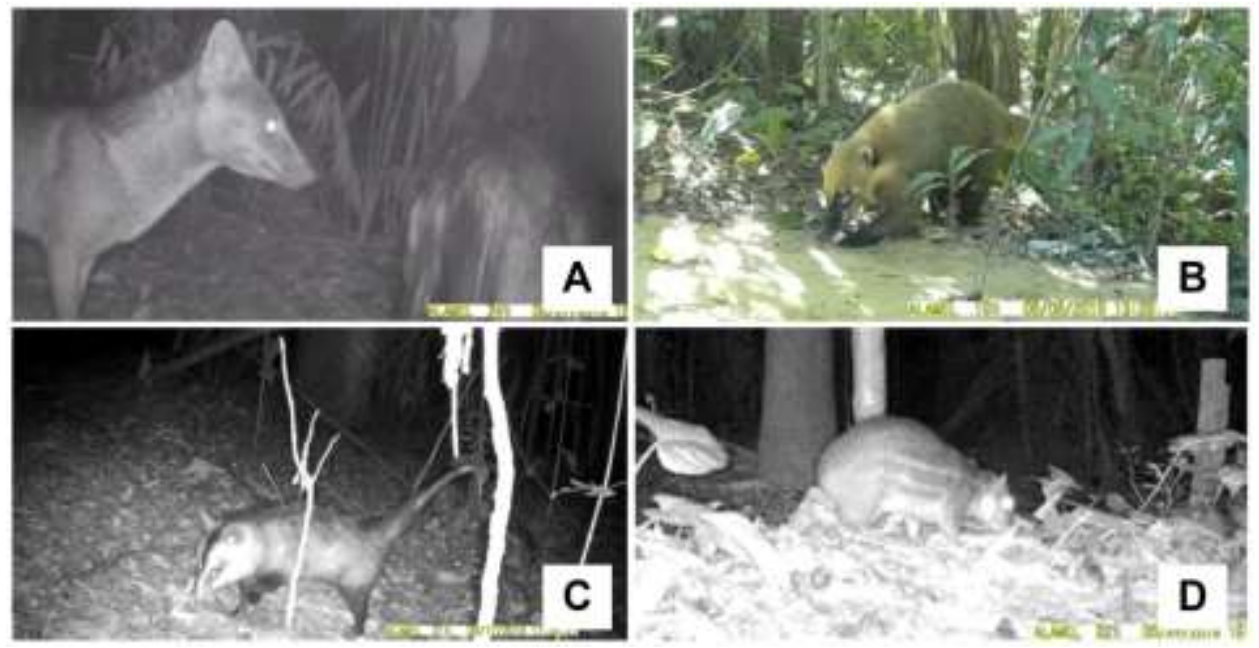

Source: Authors.

Through the active search method, with a sampling effort of $140.5 \mathrm{~km} /$ day, seven species of mammals were recorded (Figure 7), highlighting the primates, Black-pencilled Marmoset (Callithrix penicillata) and Bearded capuchin (Sapajus libidinosus), only registered by this method, corroborating with the literature, in which tree species are generally registered by it (Parry et al., 2007; Santos et al., 2013). Likewise, Santos and collaborators (2013) registered eight species of medium and large sized mammals for the active search, indicating the efficiency and importance of its use.

Figure 7. Records of active search in Zoobotanic Garden of Franca, SP.A: Black-horned capuchin (Sapajus libidinosus), B: Dog (Canis familiaris), C: Domestic cat (Felis catus), D: Capybara (Hydrochoerus hydrochaeris), E: Horse (Equus caballus) and F: Black-pencilled marmoset (Callithrix penicillata).

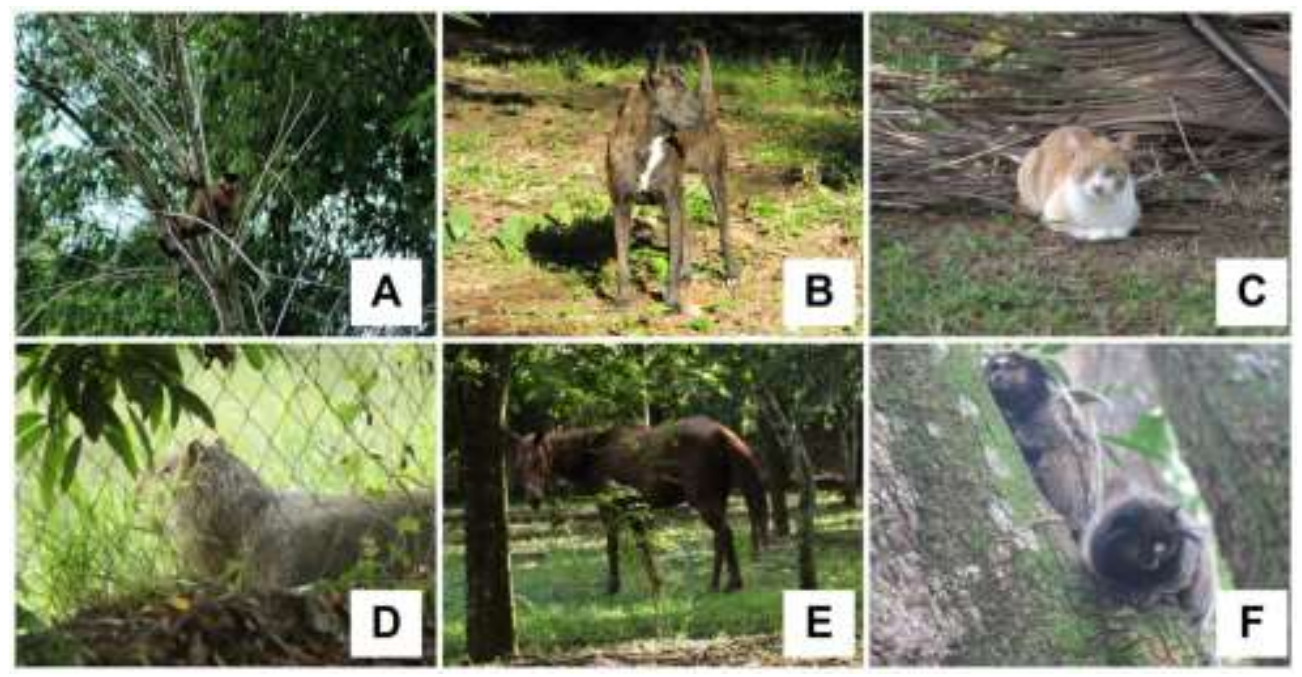

Source: Authors.

Only one species, South American coati (Nasua nasua), was common to the three sampling methods. The sand plot method showed high sampling effort, greater richness and exclusivity of species. But the camera trap method, despite the sampling effort low compared to others, obtained a sample highly successful, even with low wealth of unique species. The methods proved to be complementary, as they registered species with different behaviors and habits, contributing to the total 
sampling to be more complete (Table 2).

Table 2. Parameters analyzed for the methodologies used in the survey of medium and large mammals in the Zoobotanic Garden, Franca, SP.

\begin{tabular}{cccccc} 
Method & Sampling effort & $\begin{array}{c}\text { Sample success } \\
(\%)\end{array}$ & Number of records & Richness noted & $\begin{array}{c}\text { Number of } \\
\text { exclusive species }\end{array}$ \\
\hline Sand plots & 208 plots/day & 20,19 & 42 & 12 & 6 \\
Camera trap & 182 camera/day & 24,72 & 45 & 4 & 1 \\
Active search & $140,5 \mathrm{~km} /$ day & 25,6 & 36 & 7 & 3 \\
\hline
\end{tabular}

Source: Authors.

However, the species accumulation curve (Figure 8) did not reach an asymptote with the effort made, indicating that if the collection time were extended, the number of species sampled could be greater.

Figure 8. Accumulation curve indicating the number of species of medium and large terrestrial mammals sampled during the study.

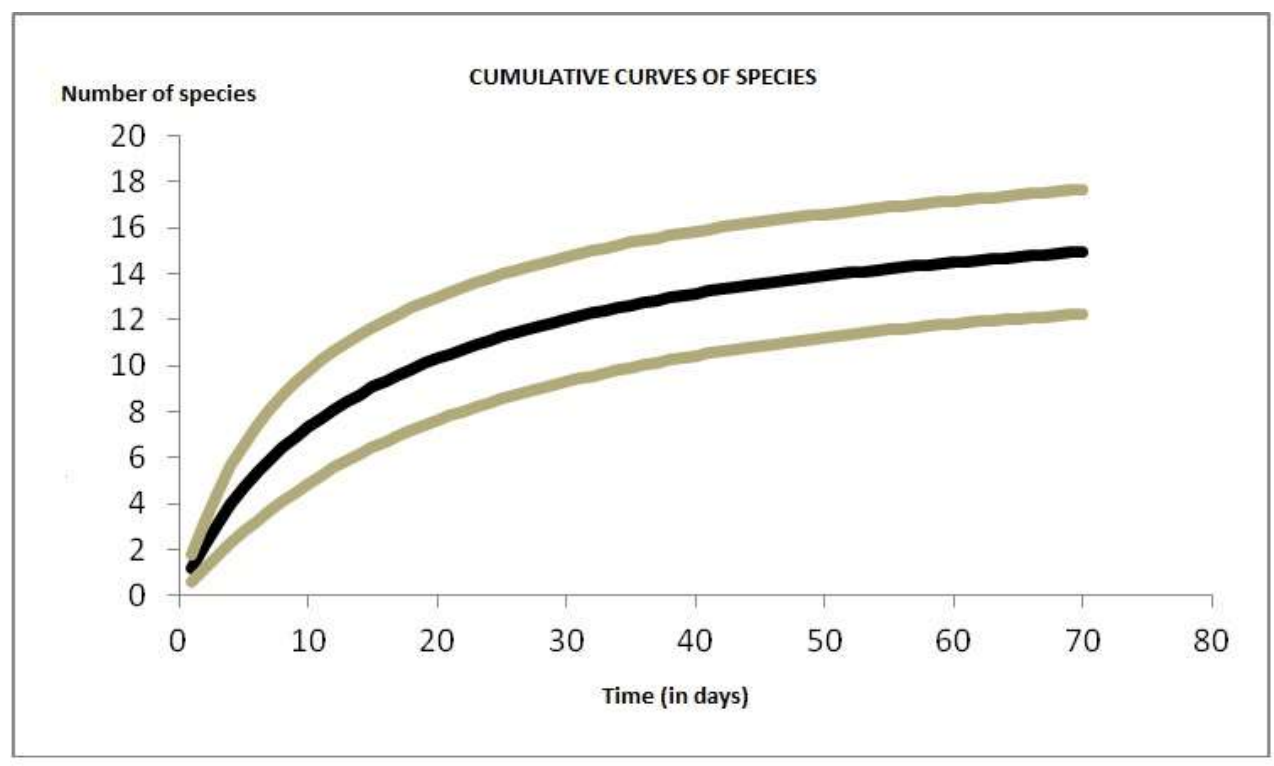

Source: Authors.

The sampled community is largely composed of opportunistic and generalist species, with few predators, which may be related to the fact that these animals, in general, need larger areas to survive (Cheida et al., 2006). Despite this, it is noted that most species found play an important role as seed dispersers, such as white-eared opossums (Didelphis albiventris) (Cantor et al., 2010), agouti (D. leporina) (Hirsch et al., 2012; Jansen, et al., 2013), crab-eating fox (C. thous) (Raíces \& Bergallo, 2010) and maned wolf (C. brachyurus) (Garcia, 2016; Veloso, 2019). Some species more vulnerable to hunting, such as nine-banded armadillo (D. novemcinctus), yellow armadillo (E. sexcinctus), agouti (Cuniculus paca) and the cavy (C. aperea) (Pereira \& Schiavetti, 2010; Cajaiba et al., 2014; Ferreira et al., 2018) were also recorded. 
The only top predator registered was maned wolf ( $C$. brachyurus), classified as vulnerable in the Brazilian list of endangered species (Instituto Chico Mendes de Conservação da Biodiversidade, 2018), main because of habitat loss through the expansion of the agricultural frontier, expressive in the region (Queirolo \& Motta Júnior, 2000). This has synanthropic behavior and shows preference for more open fields, being able enter in anthropogenic areas for resting and foraging, being lonely, forming couples only for reproduction and care of cubs (Paula et al., 2013). Considered a generalist and opportunistic species, feeding on a high density of fruits, small vertebrates, such as rodents, armadillos, marsupials and reptiles (Cheida et al., 2006; Garcia, 2016), which may include larger prey in its diet (Bestelmeyer \& Westbrook, 1998; Paula et al., 2013).

Three domestic species were recorded: dog (Canis familiaris), cat (Felis catus) and horse (Equus caballus). Their presence may be due to the increase in the degradation of the surrounding landscape, human occupation and density, and improper release, facilitating the contact between these and wild species, which can compromise the effectiveness of biodiversity conservation in this UC, as it increases the potential for disease transmission, predation and competition, resulting in species loss (Cerqueira \& Freitas, 1999; Pysek et al., 2008; Le Saout et al., 2013; Vilela \& Guedes, 2014; Lessa, 2017).

Another factor that makes the conservation difficult, whether in protected forest fragments, such as Conservation Units, or not, is the disorderly urban growth, which leads to pressure on natural resources, generating profound changes in the environmental balance (Moura-Fujimoto, 2000). In the State of São Paulo, it is estimated that about $22.9 \%$ of the territory is composed of native forest fragments (Nalon, et al., 2020), which in turn are derived from a process in which continuous forests were divided into smaller extensions and isolated in a different matrix from the original habitat (Cerqueira et al., 2003; Fahrig, 2003).

Despite the history of degradation, these forest remnants still harbor diverse flora and fauna, including even endangered species (Rodrigues \& Bononi, 2008). The species richness recorded in this study reinforces the importance of small fragments, which even when reduced and immersed in urban areas, can function as a refuge for mastofauna and serve as "stepping stones" for the displacement of individuals (Chiarello, 2000a; Chiarello, 2000b; Rocha \& Dalponte, 2006). However, these small patches of natural ecosystems continue to suffer constant negative impacts from anthropic action, threatening ecological potential and maintaining biological diversity (Costa, 2006).

Fragmentation and habitat loss have major negative effects on biodiversity (Fahrig, 2001). In order for these small fragments to continue exercising their function, it is necessary to study the factors that change their dynamics, because the condition of relatively isolated and restricted areas, as well as the characteristics of the surrounding matrix, distance between the fragments and time of isolation, have implications for biodiversity (Ricketts, 2001; Costa et al., 2005; Vasconcelos et al., 2006; Debinski, 2006). In the Franca city, only 16.6\% of the territory is composed of native vegetation (Nalon et al., 2020), which is classified as a high priority for the restoration of this vegetation, due to the presence of water sources for public supply, and the need to maintain and restore biological connectivity, protection of riparian forests and springs (Secretaria de Meio Ambiente, 2017). In this way, protected areas such as the Zoobotanic Garden are very important for the fauna, flora and natural resources conservation.

The Franca Zoobotanic Garden has a greater richness of mammal species, when compared to other medium and large sized mastofaunistic surveys in fragments of Atlantic Forest and Cerrado (Carvalho, 2009; Kanno, 2012; Santos et al., 2012, Silva \& Santos, 2015; Marafon et al., 2018). Even when compared to surveys carried out in larger areas, the study presents relatively high or equivalent species richness. Prado and collaborators (2008) registered 20 species of mammals in a forest fragment of Atlantic Forest (384.5 ha), of which nine species occur in the UC of Franca. In a survey carried out in fragments of Cerrado (685 ha), in Minas Gerais, 21 species of medium and large sized mammals were sampled (Alves, 2010), five species in common with the present study. Abreu Junior and Kohler (2009), in a RPPN in the Serra Geral Region with Atlantic Forest domain, in Rio Grande do Sul (221.39 ha), found 16 species of mammals. Therefore, the species richness of the present 
study demonstrates the importance of the small urban area for biodiversity.

When compared to studies with similar methodologies, but performed over a longer period of time, this study showed equivalent richness. In a fauna survey carried out at the headwaters of the Canoas River, also in the municipality of Franca, between April 2011 and March 2012, there were 20 species of medium and large sized mammals (Faleiros, 2012). In another survey of the same species community, carried out from January to July 2018, in the municipality of Patrocínio Paulista, 22 species of mammals were sampled (Cintra \& Oliveira, 2018). Thus, the present study shows significant sampling efficiency.

Other studies also carried out in the region showed small variations in species richness. In the survey of mammals for the cities of Franca, Cristais Paulista and Pedregulho, elaborated using secondary data from the Canoas River Hydrographic Basin, 18 species of medium and large sized mammals were sampled (De Pina et al., 2015), where six are common with the present study. In the study carried out on a stretch of the Olhos D'Água stream, in the municipality of Franca, between the years 2013 and 2015, there were 14 species of medium and large sized mammals (Silva \& Santos, 2015), being only four of them absent in the present study: red brocket (Mazama americana), crab-eating raccoon (Procyon cancrivorus), european hare (Lepus europaeus) and giant anteater (Myrmecophaga tridactyla).

In summary, it was verified by this study that the richness of medium and large sized mammals of the municipal UC Zoobotanic Garden of Franca is expressive, indicating its importance and functional role in the conservation of the regional mastofauna. Besides the importance of research that reinforces the need for conservation of small forest fragments for species of mammals.

\section{Conclusion}

The Franca municipal Conservation Unit is home to a high richness of species of medium and large sized terrestrial mammals, proving to be an important refuge for local biodiversity. Thus, it is necessary to develop an adequate management plan for the conservation of this forest fragment and its biodiversity, for better use of the site by tourists and guided visits by trained professionals, contributing to the permanence of the sampled species. Another important action is to conduct further studies of medium and large sized terrestrial mammals, in order to verify the population density and seasonal variations. The methods used were efficient for the survey, however, if the collection time was extended more species could be sampled.

\section{Acknowledgments}

University of Franca, Coordenação de Aperfeiçoamento de Pessoal de Nível Superior (CAPES, Finance Code 001) and Franca Zoobotanic Garden.

\section{References}

Abreu Junior, E. F., Casali, D. M., Garbino, G. S. T.; Loretto, D., Loss, A.C.; Marmontel, M., Nascimento, M. C., Oliveira, M. L., Pavan, S. E. \&Tirelli, F. P. (2020). Lista de Mamíferos do Brasil. Comitê de Taxonomia da Sociedade Brasileira de Mastozoologia (CT-SBMz). https://www.sbmz.org/mamiferos-dobrasil/

Abreu Junior, E. F. \& Köhler, A. (2009). Mammalian fauna of medium and large sized in the RPPN of UNISC, RS, Brazil. Biota neotropica. 9 (4), 169-174. 10.1590/S1676-06032009000400017

Alvares, C. A., Stape, J. L., Sentelhas, P. C., Gonçalves, J. L. de M. \& Sparovek, G. (2013). Köppen's climate classification map for Brazil. Meteorologische Zeitschrift, 22 (6), 711-728. 10.1127/0941-2948/2013/0507

Alves, G. B. (2010). Mamíferos de médio e grande porte em fragmentos de Cerrado na Fazenda Experimental do Glória (MG) [Master's thesis,Federal University of Uberlândia]. Repository UFU.https://repositorio.ufu.br/bitstream/123456789/13328/1/giselle.pdf

Becker, M. \& Dalponte, J. (2013). Rastros de mamíferos silvestres brasileiros:um guia de campo (3rd ed.). Technical Books.

Begon, M., Harper, J. L. \& Townsend, C. R. (1996). Ecology: individuals, population and communities (3rd ed.). Oxford: Blackwell Science. 
Beisiegel, B. M. (1999). Contribuição ao estudo da história natural do cachorro do mato, Cerdocyon thous, e do cachorro vinagre, Speothos venaticus (Publication No. 10.11606/T.47.2000.tde-10112004-084412) [Doctoraldissertation, University of São Paulo]. USP digital library.

Bestelmeyer, S. \& Westbrook, C. (1998). Maned wolf (Chrysocyon brachyurus) predation on pampas deer (Ozotoceros bezoarticus) in central Brazil.Mammalia,62 (4), 591-595.

Bird Life International.(2016). Crax fasciolata. The IUCN Red List of Threatened Species 2016. 10.2305/IUCN.UK.2016-3.RLTS.T45092100A95141387.en

Bressan, P. M., Kierulff, M. C. M. \&Sugieda. (2009). Fauna Ameaçada de Extinção no Estado de São Paulo: Vertebrados. São Paulo: Fundação Parque Zoológico de São Paulo, Secretaria do Meio Ambiente.

Burgin, C. J., Colella, J. P, Kahn, P. L. \& Upham, N. S. (2018). How many species of mammals are there?. Journal of Mammalogy, 99 (1), 1-14. 10.1093/jmammal/gyx147

Cajaiba, R. L., Silva, W. B. \& Piovesan, P. R. R. (2015). Animais silvestres utilizados como recurso alimentar em assentamentos rurais no município de Uruará, Pará, Brasil. Desenvolv. Meio Ambiente, 34, 157-168. doi.org/10.5380/dma.v34i0.38889

Câmera Municipal de Franca. (1998). Law $n^{\circ}$ 5.048, of July 1, 1998. Requirement on the creation of the Franca Zoobotanic Garden, in the specified area and other measures.https://franca.sp.leg.br/pt-br/legislacao/lei-no-5048-de-17-de-julho-de-1998

Cantor, M., Ferreira, L. A., Silva, W. R. \&Setz, E. Z. F. (2010). Potencial dispersão de sementes por Didelphis albiventris (Marsupialia, Didelphidae) em ambiente altamente perturbado. Biota Neotropica, 10 (2), 45-51. 10.1590/S1676-06032010000200004

Carvalho Júnior, O. \& Luz, N. C. (2008). Pegadas. UFPA, Belém, Brasil. (Série Boas práticas, 3). http://livroaberto.ufpa.br/jspui/handle/prefix/146>

Carvalho, F. C. (2010). Levantamento da mastofauna terrestre de médio e grande porte em remanescente de floresta neotropical - Itatinga, SP[Undergraduate thesis, São Paulo State University].UNESP InstitutionalRepository. https://repositorio.un esp.br/há ndle/11449/118570

Cerqueira R., Brant, A., Nascimento, M. T. \& Pardini, R. (2003). Fragmentação: alguns conceitos. In: D. M. Rambaldi, D. A. S, Oliveira (Orgs.). Fragmentação de ecossistemas: causas, efeitos sobre a biodiversidade e recomendações de políticas públicas (pp. 23-65). MMA: SBF.https://www.terrabrasilis.org.br/ecotecadigital/pdf/serie-biodiversidade--06-fragmentacao-de-ecossistemas-causas-efeitos-sobre-a-biodiversidade-erecomendacao-de-politicas-publicas.pdf

Cerqueira, R. \& Freitas, S. R. (1999). A new study method of microhabitat structure of small mammals. Revista Brasileira de Biologia, 59 (2), $219-223$. $10.1590 /$ S0034-71081999000200006

Cheida, C.C., Nakano-Oliveira, E., Fusco Costa, R., Rocha-Mendes, F. \& Quadros, J. (2006). Ordem Carnívora, 231-275. In: N.R. Reis, A.L., Perachi, W.A. \& Pedro e I.P. Lima (Eds.). Mamíferos do Brasil. UEL, Londrina, Brasil.

Chiarello, A. G. (2000a). Density and population size of mammals in remnants of Brazilian Atlantic forest. Conservation Biology, 14 (6), 1649-1657. 10.1111/j.1523-1739.2000.99071.x

Chiarello, A. G. (2000b). Conservation value of native forest fragment in region of extensive agriculture. Revista Brasileira de Biologia, 60 (2), 237247.10.1590/S0034-71082000000200007

Cintra, G. C. \& Oliveira, L. S. (2018). Levantamento preliminar da mastofauna de médio e grande porte de fragmento florestal e mata de galeria na Fazenda Santo Antônio, em Patrocínio Paulista-SP [Unpublished undergraduate thesis]. University of Franca.

Climatempo. (2019). Climatologia do Município de Franca, São Paulo, Brasil. https://www.climatempo.com.br/climatologia/443/franca-sp

Cooke, R. S. C., Eigenbrod, F. \& Bates, A. E. (2019). Projected losses of global mammal and bird ecological strategies. Nature Communications, 10 (2279), 18. $10.1038 / \mathrm{s} 41467-019-10284-\mathrm{Z}$

Costa, L. P., Leite, Y. L. R., Mendes, S. L. \& Ditchfield, A. D., (2005). Mammal conservation in Brazil. Conservation Biology, 19 (3), 672679.https://www.jstor.org/stable/3591053

Costa, R. (2006). Impactos sobre remanescentes de florestas de Mata Atlântica na zona oeste da grande São Paulo: um estudo de caso da mata da Fazenda Tizo (Publication No.10.11606/D.8.2006.tde-21062007-14082). [Master's thesis, University of São Paulo]. USP digital library.

Courtenay, O. \&Maffei, L. (2004).Crab-eating fox Cerdocyon thous (Linnaeus, 1766), 32-38. In: Sillero-Zubiri, C., Hoffmann, M. \& Macdonald, D. W. (2004) (eds.). Canids: foxes, wolves, jackals and dogs. Status survey and conservation action plan, IUCN.

Cullen Júnior, L., Rudran, R. \&Valladares-Padua, C. (2012). Métodos de Estudos em Biologia da Conservação e Manejo da Vida Silvestre. Curitiba, Paraná: UFPR.

De Pina, L. F. (2015). Brasil: conhecimento atual e perspectivas. Mamíferos da bacia hidrográfica do rio canoas, São Paulo e Minas Gerais,Franca, Brasil.

De Vivo, M., Carmignotto, A. P., Gregorin, R., Hingst-zaher, E., Iack-Ximenes, G. E., Miretzki, M., Percequillo, A. R., Rollo Junior, M. M., Rossi, R. V. \& Taddei, V. A. (2011).Checklist dos mamíferos do Estado de São Paulo.Brasil. Biota Neotropica, 11 (1), 111 - 131. https://doi.org/10.1590/S167606032011000500007

Dotta, G. \& Verdade, L. M. (2007).Trophic categories in a mammal assemblage: diversity in an agricultural landscape. Biota Neotropica, 7 (2), 287292.https://www.biotaneotropica.org.br/v7n2/pt/abstract?short-communication+bn01207022007

Fahrig L. (2001). How much habitat is enough? Biol. Conserv, 100, 65-74. 10.1016/S0006-3207(00)00208-1 
Fahrig, L. (2003).Effects of habitat fragmentation on biodiversity. Annual Review of Ecology Evolution and Systematics, 34 (1), 487-515. 10.1146/annurev.ecolsys.34.011802.132419

Faleiros, T. O. (2012). Levantamento faunístico em nascentes do rio Canoas na fazenda São Roque no município de Franca - SP [Post graduation thesis,University of Franca]. Cruzeiro do Sul Educational.

Ferreira, E., Pessoa, S., Aximoff, I., Marins, J. \& Pontes, J. (2018). Aves e mamíferos cinegéticos nas unidades de conservação de proteção integral do Estado do Rio de Janeiro. Revista ineana, 6 (3), 38-53. Researchgate. https://www.researchgate.net/publication/331593272_Aves_e_mamiferos_cinegeticos _nas_unidades_de_conservacao_de_protecao_integral_do_Estado_do_Rio_de_Janeiro

Franca. (2016). Conselho de Defesa do Patrimônio Histórico. Relação dos Patrimônios tombados no municicípio de Franca. https://www.franca.sp.gov.br/index.php?option=com_phocadownload\&view=category\&id=253:bens-tombados\&Itemid=648

Francisco, G. O. \& Nascif Jr., I. A. (2009) Estudo da Quiropterofauna no Município de Franca - SP [Undergraduate thesis, University of Franca]. Cruzeiro do Sul Educational.

Garcia, P. B. (2016). Disponibilidade de frutos, frugivoria e dispersão de sementes por loboguará (Chrysocyon brachyurus) no Parque Estadual do Rio Preto, $M G$.[Master'sthesis,StateUniversity of Minas Gerais]. UFMG Repository.https://repositorio.ufmg.br/handle/1843/BUBD-ADXFP7

Hammer, O., Harper, D. A. T. \& Ryan, P. D. (2001) PAST. Paleontological Statistics software package for education and data analysis.Palaeontologia Electronica, Oslo, 41 (1), 1-9.https://palaeo-electronica.org/2001_1/past/issue1_01.htm

Hirsch, Bt., Kays, R., Pereira, Ve. \& Jansen, P. A. (2012). Directed seed dispersal towards areas with low conspecific tree density by a scatter-hoarding rodent. Ecology Letters, 15 (12), 1423-1429. 10.1111/ele.12000

ICMBIO. Instituto Chico Mendes de Conservação da Biodiversidade (2018). Livro Vermelho da Fauna Brasileira Ameaçada de Extinção: Volume II Mamíferos. In: Instituto Chico Mendes de Conservação da Biodiversidade. (Org.). Livro Vermelho da Fauna Brasileira Ameaçada de Extinção. Brasília: ICMBio.

ICMBIO. Instituto Chico Mendes de Conservação da Biodiversidade (2018). Livro Vermelho da Fauna Brasileira Ameaçada de Extinção. MMA, Brasília, DF.

IUCN - International Union for Conservation of Nature and Natural Resources. (2001). IUCN Red List Categories and Criteria: Version 3.1. IUCN Species Survival Comission.IUCN, Gland, Switzerland and Cambridge, UK.

Jansen, P. A., Hirsch, B. T., Emsens, W. J., Zamora-Gutierrez, V., Wikelskyl, M. \& Kays, R. (2013). Thieving rodents as substitute dispersers of megafaunal seeds.Proceedings of the National Academy of Sciences, 109 (31), 12610-12615. 10.1073/pnas.1205184109

Kanno, B. I. (2012). Levantamento da mastofauna terrestre de médio e grande porte em remanescentes florestais na Microbacia Córrego da Cascata Botucatu, SP [Undergraduate thesis, State University of São Paulo Julio de Mesquita Filho]. UNESP Institutional Repository.https://repositorio.unesp.br/handle/11449/119513

Köche, J. C. (2011). Fundamentos de metodologia científica: teoria da ciência e iniciação à pesquisa. Vozes.

Le Saout, S., Hoffmann, M., Shi, Y., Hughes, A., Bernard, C., Brooks, T. M. \& Rodrigues, A. S. (2013). Protected areas and effective biodiversity conservation. Science, 342 (6160), 803-805. 10.1126/science.1239268

Lemos, F. G., Facure, K. G., Azevedo, F. C. (2011).A first approach to the comparative ecology of the hoary fox and the crab-eating fox in a fragmented human altered landscape in the Cerrado biome at Central Brazil. In L.M.Rosalino \& C.Gheler-Costa (Eds.). Middle-sized carnivores in agricultural landscapes (pp.143-160).Nova Science Publishers.

Lessa, I. C. M. (2017). O impacto de cães domésticos em uma Unidade de Conservação do Cerrado [Doctoral dissertation, University of Brasília]. UNB Repository. https://repositorio.unb.br/handle/10482/31980

Lewinsohn, T. M. \& Prado, P. I. (2002). Biodiversidade brasileira: síntese do estado atual do conhecimento. São Paulo: Contexto. http://www.bdpa.cnptia.embrapa.br/consulta/busca $? \mathrm{~b}=\mathrm{ad} \& \mathrm{id}=566932 \&$ biblioteca $=$ CPAC\&busca=autoria:\%22PRADO, $\% 20 \mathrm{P} . \% 22 \& \mathrm{qFacets}=\mathrm{autoria}: \% 22 \mathrm{PRA}$ DO,\%20P.\%22\&sort=\&paginacao=t\&paginaAtual $=1$

Marafon, A. T., Copini, A. C., Freire, C. G., Jesus, A. F., Santos, J. T. \& Appi, L. A. (2018). Mastofauna não voadora de médio e grande porte em área de mosaico de vegetação nativa e exótica na mesorregião Oeste catarinense, Brasil. InterfacEHS, 13 (2), 53 - 67. http://www3.sp.se nac.br/hotsites/blogs/InterfacEHS/wp-content/uploads/2019/02/229_InterfacEHS_ArtigoRevisado.pdf

Marques, R. \& Mazim (2005). A utilização de armadilhas fotográficas para o estudo de mamíferos de médio e grande porte. Caderno La Salle XI. 2, 219228. Researchgate.

https://www.researchgate.net/publication/260244590_A_utilizacao_de_armadilhas_fotograficas_para_o_estudo_de_mamiferos_de_medio_e_grande_porte

Marquetti, E. H. (1991). Franca: Geografia e História do município de Franca. Franca: W. Veríssimo.

Mazzolli, M. (2006). Persistência e riqueza de mamíferos focais em sistemas agropecuários no planalto meridional brasileiro [Doctoral dissertation, Federal University of Rio Grande do Sul]. LUME Digital Repository. https://lume.ufrgs.br/handle/10183/7660

Mittermeier, R. A., Myres, N. \& Mittermeyer, G. C. (2000).Hotspots: earth's biologically richest and most endangered terrestrial ecoregions, CEMEX, Conservation International. 
Mittermeier, R. A., Robles-Gil, P. \& Mittermeier, C. (1997). Megadiversity. Earth's Biological Wealthiest Nations. Mexico City: CEMEX/AgrupaciónSierra Madre.

Moro-Rios, R. F., Silva-Pereira, J. E., Silva, P. W., Moura-Britto, Mauro \& Patrocínio, D. N. M. (2008). Manual de Rastros da Fauna Paranaense, Curitiba: Instituto Ambiental do Paraná.

Motta Jr, J. C., Lombardi, J. A. \&Talamoni, S. A. (1994). Notes on crab-eating fox (Dusicyonthous) seed dispersal and food habits in southeastern Brazil. Mammalia, 58, 156- 159.10.1590/S1676-06032009000200027

Moura-Fujimoto, N. S. V. (2000). Urbanização brasileira e a qualidade ambiental.In: D. M. A.Suertegaray, L. A. Basso, \& R.Verdum.Ambiente e lugar no urbano: a grande Porto Alegre. Associação dos Geógrafos Brasileiros.https://lume.ufrgs.br/handle/10183/215355

Nalon, M. A., Matsukuma, C. K \& Pavão, M. (2020). Inventário florestal da vegetação natural do Estado de São Paulo. São Paulo: Secretaria do Meio Ambiente/Instituto Florestal. https://smastr16.blob.core.windows.net/home/2020/07/inventarioflorestal2020.pdf

Karanth, K. U., Nichols, J.D.,Cullen Júnior, L. Armadilhamento fotográfico de grandes felinos: algumas considerações importantes.. In: L. Cullen Jr, R. Rudran e C. Valadares-Pádua (Eds.), Métodos de estudos em biologia da conservação e manejo da vida silvestre (pp. 269-284). Curitiba: UFPR, 2003.

Paglia, A. P., Fonseca, G. A. B. da, Rylands, A. B., Herrmann, G., Aguiar, L. M. S., Chiarello, A. G., et al. (2012). Lista anotada dos mamíferos do Brasil. In Occasional papers in conservation biology. Conservação Internacional.

Pardini, R., Ditt; E. H., Cullen Junior, L., Bassi, C. \&Rudran, R. (2003). Levantamento rápido de mamíferos terrestres de médio e grande porte. In: Métodos de estudos em biologia da conservação e manejo da vida silvestre. Curitiba: Universidade Federal do Paraná e Fundação o Boticário de Proteção da Natureza,

Parry, L., Barlow, J., \& Peres, C. A. (2007). Large-vertebrate assemblages of primary and secondary forests in the Brazilian Amazon. Journal of Tropical Ecology, 23(6), 653-662. 1017/S0266467407004506

Paula, R. C., Rodrigues, F. H. G., Queirolo, D., Jorge, R. P. S., Lemos, F. G. \& Rodrigues, L. A. (2013). Avaliação do estado de conservação do Lobo-guará Chysocyon brachyurus (Illiger, 1815) no Brasil. Biodiversida de Brasileira, 3 (1), 146-159. https://www.icmbio.gov.br/portal/im ages/stories/biodiversidade/fauna-brasileira/avaliacao-do-risco/carnivoros/lobo-guara_chrysocyon_brachyurus.pdf

Pereira, A. S, Shitsuka, D. M., José Parreira, F. J., Shitsuka, R. (2018). Metodologia da pesquisa científica. UFSM. https://repositorio.ufsm.br/bitstream/hand le/1/15824/Lic_Computacao_Metodologia-Pesquisa-Cientifica.pdf?sequence=1

Pereira, J. P. R. \& Schiavetti, A. (2010). Knowledge And Faunal Game Uses By Indigenous Hunters “Tupinambá From Olivença” (Bahia). Biota Neotropica, 10, (1). https://www.biotaneotropica.org.br/v10n1/en/abstract?article+bn03210012010

Prado, M. R., Rocha, E. C. \& Giudice, G. M. L. D. (2008). Mamíferos de médio e grande porte em um fragmento de mata atlântica, Minas Gerais, Brasil, Revista Árvore,32 (4), 741-749. 10.1590/S0100-67622008000400016

Pysek, P., Richardson, D. M., Pergl, J., Jarosik, V., Sixtova, Z. \& Weber, E. (2008). Geographical and taxonomic biases in invasion ecology,Trends in ecology and evolution, 23, 237-244. 10.1016/j.tree.2008.02.002

Queirolo, D., \& Motta Júnior, J. C. (2000). Possível influência das mudanças de paisagem no parque nacional da Serra da Canastra - MG na dieta do loboguará (Chrysocyn brachyurus). Campo Grande: Rede Nacional Pró-Unidade de Conservação/Fundação O Boticário de Proteção à Natureza.

Raíces, D. S \&Bergallo, H. G. (2010). Diet and seed dispersion of the crab-eaten fox, Cerdocyon thous (Linnaeus, 1766) in Restinga de Jurubatiba National Park, Rio de Janeiro State, Brazil. Neotropical Biology and Conservation, 5 (1), 24-30. 10.4013/nbc.2010.51.04

Ramos Júnior, V. A., Pessuti, C.\&Chieregatto, C. A. F. S.(2003). Guia de identificação dos canídeos silvestres brasileiros. Sorocaba, Comunicação ambiental, 35 .

Ricketts, T. (2001).The Matrix Matters: Effective Isolation in Fragmented Landscapes. The American naturalist, 158 (1) 87-99.10.1086/320863

Rocha, E. C. \& Dalponte, J. C. (2006). Composição e caracterização da fauna de mamíferos de médio e grande porte em uma pequena reserva de Cerrado em Mato Grosso, Brasil, Revista Árvore, 30 (4), 669-678. 10.1590/S0100-67622006000400021

Rodrigues, R. R. \& Bononi, V. L. R. (2008). Diretrizes para a conservação e restauração da biodiversidade no estado de São Paulo, São Paulo: Instituto de Botânica/Programa BIOTA/FAPESP.

Santos, C. F., Bueno, B. \& Casella, J. (2013). Comparação entre métodos de amostragem e eficiência de iscas na atração de mamíferos de médio, Neotropical Biology and Conservation, 8 (3), 156-164. 10.4013/nbc.2013.83.06

Santos, M. B., Castro, R. J., Vizzotto, P. C., Leandro, D. S. \& Pamplona, E. R. (2012). Levantamento de mamíferos de um fragmento florestal de Rondonópolis, Mato Grosso. Biodiversidade, 11 (1), 115 - 121. https://periodicoscientificos.ufmt.br/ojs/index.php/biodiversidade/article/view/712

Silva, C. R. (2001). Riqueza e diversidade de mamíferos não-voadores em um mosaico formado por plantios de Eucalyptus saligna e remanescentes de Floresta Atlântica no município de Pilar do Sul, SP (Publication No. 10.11606/D.11.2002.tde-18072002-151132) [Master'sthesis, Luiz de Queiroz College of Agriculture].

Silva, J. S. G. \& Santos, L. F. R. (2015). Mastofauna de médio a grande porte associada à vegetação ripária periurbana do Ribeirão Olhos d'Água no Município de Franca, SP .[Unpublished undergraduate thesis].University of Franca.

SMA.Secretaria do Meio Ambiente. (2017). Resolution SMA No. 7 of January 18, 2017. Provides for the criteria and parameters for environmental compensation of areas subject to authorization request for the suppression of native vegetation, cutting of isolated trees and for interventions in Permanent 
Research, Society and Development, v. 10, n. 8, e11710817043, 2021

(CC BY 4.0) | ISSN 2525-3409 | DOI: http://dx.doi.org/10.33448/rsd-v10i8.17043

Preservation Areas in the State of São Paulo. Diário Oficial do Estado, Seção 1 , 5457.https://www.infraestruturameioambiente.sp.gov.br/legislacao/2017/01/resolucao-sma-07-2017/

SMA. Secretaria do Meio Ambiente. (2018). Decree 63.853, of 11/27/2018. It declares wildlife species in the State of São Paulo regionally extinct, endangered, near-threatened and those with insufficient data for assessment, and takes related measures. https://www.al.sp.gov.br/repositorio/legislacao/decreto/2018/decreto-63853-27.11.2018.html

Specieslink. (2019). SpeciesLink Network http://splink.org.br/

Srbek-Araujo, A. C. \& Chiarello, A. G. (2007). Armadilhas fotográficas na amostragem de mamíferos: considerações metodológias e comparação de equipamentos. Revista Brasileira de Zoologia, 24 (3), 647-656. 10.1590/S0101-81752007000300016

Terborgh, J. \&Soulé, M. E. (1999.) The role of top carnivores in regulating terrestrial ecosystems, Continental Conservation, 39-64. https://pubs.er.usgs.gov/publication/81567

Tomas, W. M. \& G. H. B., Miranda. (2003). Uso de armadilhas fotográficas em levantamentos populacionais, 243-267. In: L. Cullen Jr, R. Rudran \& C. Valladares-padua (Eds). (2003) Métodos de estudo em biologia da conservação e manejo da vida silvestre. Curitiba, UFPR.

Tonhasca Junior, A. (2005). Ecologia e história natural da Mata Atlântica, Interciência, Rio de Janeiro, Brasil.

Valsecchi, J., Marmontel, M., Franco, C. L. B., Cavalcante, D. P., Cobra, I. V. D., Lima, I. J.,Lanna, J. M., Ferreira, M. T. M., Nassar, P. M., Botero-Arias, R. \& Monteiro, V. (2017). Atualização e composição da lista - Novas Espécies de Vertebrados e Plantas na Amazônia 2014-2015. WWF-Brasil Instituto de Desenvolvimento Sustentável Mamirauá.Brasília: WWF-Brasil, 2017.

Veloso, A. C.(2019). Dieta e dispersão de sementes de lobeira pelo lobo-guará (Chrysocyon brachyurus) em área de Cerrado, com reflorestamento de eucalipto como matriz de entorno - Minas Gerais [Master's thesis, Federal University of Uberlândia]. UFU Repository. https://repositorio.ufu.br/handle/123456789/27043

Vieira, N. M. (1971). Geografia de Franca: Aspectos físicos. Franca: Comércio da Franca, Brasil.

Vilela, A. L. O. \& Guedes-Lamin, V. (2014). Cães domésticos em Unidades de Conservação: Impactos e controle. Holos Environment, 14 (2), 198 210.10.14295/holos.v14i2.8192

Wikimedia. (2019). Map of São Paulo State. commons.wikimedia.org/wiki/File:SaoPaulo_MesoMicroMunicip.svg

Wolfart, R. M., Fré, M., Lucas, E. M. \& Miranda, G. B. (2013).Terrestrial mammals in an Atlantic Forest remnant, Paraná, Brazil. Biotemas, 26 (4), 111-119. https://periodicos.ufsc.br/index.php/biotemas 